\title{
CHANGES IN PHOTOSYNTHETIC PIGMENTS, OSMOLYTES AND ANTIOXIDANTS OF INDIAN MUSTARD BY DROUGHT AND EXOGENOUS POLYAMINES
}

\author{
Elham Mostafaei, ${ }^{1}$ Saeid Zehtab-Salmasi, ${ }^{1}$ Yahya Salehi-Lisar ${ }^{2}$ \\ and KaZEM GHASSEMI-GOLEZANI ${ }^{1}$ *
}

${ }^{1}$ Department of Plant Eco-physiology, Faculty of Agriculture, University of Tabriz, Tabriz, Iran

${ }^{2}$ Department of Plant Sciences, Faculty of Natural Sciences, University of Tabriz, Tabriz, Iran

(Received: March 18, 2018; accepted: May 22, 2018)

\begin{abstract}
A pot experiment was performed as factorial based on randomized complete block design with three replications, to assess the effects of $1 \mathrm{mM}$ spermidine (SPD) and $1 \mathrm{mM}$ putrescine (PUT) on Indian mustard (Brassica Juncea L.) under different levels of watering $(100,75,50$ and $25 \%$ of field capacity). Chlorophyll a and $\mathrm{b}$ contents decreased, but the ratio of $\mathrm{Chl} \mathrm{a} / \mathrm{b}$ and carotenoid content increased with decreasing water supply. Foliar sprays of polyamines improved chlorophylls $\mathrm{a}$ and $\mathrm{b}$ and carotenoid contents, while the ratio of $\mathrm{Chl} \mathrm{a} / \mathrm{b}$ was reduced by these growth regulators. Relative water content, glycine betaine, proteins and soluble sugars contents were increased, but proline content was decreased by exogenous polyamines under limited water supply. Antioxidant enzyme (POX, CAT, SOD and APX) activities were enhanced by drought stress and polyamine treatments. This resulted in lower electrolyte leakage and lipid peroxidation (less MDA) under stressful conditions. The present results indicate that exogenous polyamines such as putrescine and spermidine can alleviate some of the deleterious impacts of water limitation on Indian mustard.
\end{abstract}

Keywords: Antioxidants - drought - osmolytes - putrescine - spermidine

\section{INTRODUCTION}

A number of abiotic stresses like drought, temperature, and salinity, usually reduce crop yield [18]. It has been approximated that crops reach only $25 \%$ of their likely yield, because of the damaging effects of environmental stresses [7]. Water shortage induces a set of physiological and biochemical reactions in plants, depending on the severity and duration of the stress occurrence, and also on the plant developmental stage and morphology $[3,39]$. As an adaptive and protection mechanism, plant hormonal and signaling networks are involved in various ways to manage stress under different abiotic conditions [32].

Environmental stress induces the accumulation of reactive oxygen species (ROS) in the cells, which can cause severe oxidative damage in the plants, thus inhibiting growth and grain yield $[28,42]$. Whether ROS will act as damaging or signaling molecule depends on the delicate equilibrium between ROS production and scaveng-

*Corresponding author; e-mail address: golezani@gmail.com 
ing [31]. When environmental condition is favorable for plants, ROS is constantly generated at low levels scavenged then by various antioxidant mechanisms [14]. However, higher production of ROS under environmental stresses can damage the cells by peroxidation of lipids, oxidation of proteins and enzyme inhibition [41]. To avoid potential damage caused by ROS to cellular components, as well as to maintain growth, metabolism, development, and overall productivity, the balance between production and elimination of ROS at the intracellular level must be rigorously regulated. This detoxification of ROS could be achieved by enzymatic and non-enzymatic antioxidants $[26,27]$.

Brassica oilseeds are the major world source of vegetable oil. These crops represent a substantial contribution to the production of food, and almost their all parts are used in human livelihood. Its oil has special fatty acid profile and rich source of natural anti-oxidants and other cytotoxic phytochemicals. However, over the past couple of decades Brassica oilseeds has become a more dependable source of erucic acid [44]. Brassica developes will in high rainfall areas, whereas it grows, little in low rainfall areas [37]. Reduction of the yield of Brassica due to drought stress has been reported by a number of authors [24, 33]. However, the influence of various exogenous growth regulators in alleviation of drought stress is still less known.

Polyamines are unsaturated hydrocarbons, with two or more primary amino groups. The diamine putrescine and triamine spermidine are ubiquitous in nature [40] and involved in a variety of processes, such as transcription, RNA and protein synthesis and enzyme activation [45]. A number of physiological regulatory process involved in the control of cell division, embryogenesis, root formation, fruit ripening, perception of biotic and abiotic stress response are modulated by polyamines [22]. Moreover, polyamines are effective in the up- and downregulation of physiological activities under environmental stresses [40]. However, polyamine application for down regulating the oxidative stress is less studied. Therefore, it could be hypothesized that polyamines could interacting with cellular redox processes in tissues to reduce ROS-induced oxidative damage. The mechanism of such polyamine mediated resistance to oxidative stress is not clear so far. Thus, this research was carried out to investigate the possible roles of putrescine and spermidine in alleviating drought and oxidative stress of Indian mustard (Brassica juncea L.).

\section{MATERIALS AND METHODS}

\section{Experimental design}

A pot experiment was performed as factorial based on randomized complete block design with three replications in a glass greenhouse at the University of Tabriz, to investigate the effects of $1 \mathrm{mM}$ Spermidine (SPD) and $1 \mathrm{mM}$ Putrescine (PUT) on Indian mustard subjected to water limitation (100, 75, 50 and $25 \%$ of field capacity).

Each pot was filled with $1 \mathrm{~kg}$ perlite and then 30 seeds were sown in $1 \mathrm{~cm}$ depth of each pot. All 36 pots were placed in a greenhouse with natural light and photoperiod. 
Day-night mean temperatures were $25-22{ }^{\circ} \mathrm{C}$ and relative humidity was $35-40 \%$. After seedling establishment, plants were thinned to keep 10 plants per pot. The pots were weighed regularly, and the loss of water was compensated by Hoagland solution to achieve $100 \%$ field capacity (FC). The polyamines were sprayed on plants up to run off from leaves, once at vegetative stage and once at full-flowering. At the same time control plants were sprayed by tap water. A week after the last treatment, a plant from each pot was harvested and laboratory tests were performed.

\section{Photosynthetic pigments}

The content of Chl a, b and total chlorophyll, as well as carotenoids in leaves as measured by the method of Arnon [2]. The fresh leaves were cut and $0.2 \mathrm{~g}$ from each sample was placed in a tube containing $10 \mathrm{ml}$ of $80 \%$ acetone at $4{ }^{\circ} \mathrm{C}$ for $24 \mathrm{~h}$. The extracted samples were centrifuged at $10,000 \mathrm{~g}$ for $5 \mathrm{~min}$. Absorbance of the supernatant (upper layer) was read at 645, 663, 480 and $510 \mathrm{~nm}$ by a spectrophotometer (Model Analytik Jena Spekol 1500, Germany).

\section{Leaf water content}

A plant was taken from each pot just before flowering. All the leaves were detached from the stem and weighed. Thereafter, the leaves were oven dried at $80{ }^{\circ} \mathrm{C}$ for $24 \mathrm{~h}$ and re-weighed. The leaf water content was calculated as $[(\mathrm{FW}-\mathrm{DW}) / \mathrm{FW}] \times 100$, where FW and DW are leaf fresh and dry weights, respectively.

\section{Proline}

The method of Bates et al. [4] was used to measure proline content of Brassica leaves. The $500 \mathrm{mg}$ of a leaf sample was homogenized in $5 \mathrm{ml}$ of $3 \%$ sulphosalycylic acid and thereafter $2 \mathrm{ml}$ of the extracted sample was poured into a plastic tube and then 2 $\mathrm{ml}$ of glacial acetic acid and $2 \mathrm{ml}$ of ninhydrin were added to this mixture. The samples were heated at $100{ }^{\circ} \mathrm{C}$ for an hour in a Bain Marie (BM-15 Bain Marie, Magapor SL, Spain). Then the samples were cooled to room temperature and the mixture was extracted with toluene, and the absorbance of upper layer was measured at $520 \mathrm{~nm}$. Proline content of leaves was determined with the calibration curve of pure proline and expressed as $\mathrm{mg} \mathrm{g}^{-1}$ fresh weight (FW).

\section{Glycine betaine}

For measuring the glycine betaine (GB) content in leaves, $500 \mathrm{mg}$ of leaf samples were ground and mixed with $5 \mathrm{ml}$ of toluene-water mixture ( $0.05 \%$ toluene) in a 20 
$\mathrm{ml}$ plastic tube. All of the tubes were shaken for $24 \mathrm{~h}$ at room temperature $\left(25^{\circ} \mathrm{C}\right)$. A $1 \mathrm{ml}$ of $2 \mathrm{~N} \mathrm{HCl}$ and $0.1 \mathrm{ml}$ of potassium tri-iodide solution was added to $0.5 \mathrm{ml}$ of the sample and shaken in an ice-cold water bath for $90 \mathrm{~min}$. Upper aqueous layer was removed and the optical density of the organic layer was read at $365 \mathrm{~nm}$. Glycine betaine content was calculated by a standard curve and expressed as $\mathrm{mg} \mathrm{g}^{-1}$ dry weight (DW) [17].

\section{Soluble sugars}

The soluble sugar content of leaves was measured by the method of phenol sulphuric acid [21] and expressed as $\mathrm{mg} \mathrm{g}^{-1} \mathrm{DW}$, by a calibration curve of pure glucose.

\section{Antioxidant enzymes activities}

For measuring soluble protein content, $1000 \mathrm{mg}$ of leaf samples were homogenized with $4 \mathrm{ml} \mathrm{Na-phosphate} \mathrm{buffer,} \mathrm{then} \mathrm{centrifuged} \mathrm{at} \mathrm{12,000} \mathrm{g} \mathrm{for} 10 \mathrm{~min}$. Supernatants were collected and the absorbance was recorded at $595 \mathrm{~nm}$ [8], using a UV-VIS spectrophotometer.

The activity of peroxidase (POX) was measured by the change of absorption at 470 $\mathrm{nm}$ due to guaiacol oxidation. The activity was assayed for $2 \mathrm{~min}$ in a reaction solution containing $2.5 \mathrm{ml}$ of $50 \mathrm{mM}$ potassium phosphate buffer $(\mathrm{pH}=7.0), 1 \mathrm{ml}$ of $1 \%$ guaiacol, $1 \mathrm{ml}$ of $1 \% \mathrm{H}_{2} \mathrm{O}_{2}$ and $0.3 \mathrm{ml}$ of enzyme extract [16]. The enzyme activity was calculated using the extinction coefficient of tetra-guaiacol $\left(26.60 \mathrm{mM}^{-1} \mathrm{~cm}^{-1}\right.$ extinction coefficient).

Ascorbate-peroxidase (APX) activity was measured by the method of Nakano and Asada [30] with monitoring the decrease in absorbance at $290 \mathrm{~nm}$ and expressed as $\mathrm{Ug}^{-1}$ FW. Superoxide dismutase (SOD) activity was measured as the volume of enzyme affecting $50 \%$ of the maximum inhibition of decrease in nitro blue tetrazolium. Catalase (CAT) activity was estimated by alterations in absorbance at $240 \mathrm{~nm}$ $\left(\mathrm{Ug}^{-1} \mathrm{FW}\right)$ [43].

The activity of superoxide dismutase (SOD) was determined according to Giannopolitis and Ries [15]. A reaction mixture containing $200 \mu \mathrm{L}$ of $50 \mathrm{mM}$ potassium phosphate buffer ( $\mathrm{pH}=7.8$ ), $300 \mu \mathrm{L}$ of $12 \mathrm{mM}$ methionine, $300 \mu \mathrm{L}$ of $75 \mu \mathrm{M}$ NBT and $1 \mathrm{~mL}$ of $50 \mathrm{mM} \mathrm{Na}_{2} \mathrm{CO}_{3}$ was used as control. $300 \mu$ of the enzyme extract were added to the same mixture, and then $30 \mu \mathrm{L}$ of $1 \mu \mathrm{M}$ riboflavin were mixed with each of the mixtures. The tubes were shaken and placed $30 \mathrm{~cm}$ far from light source consisting of a $40 \mathrm{~W}$ fluorescent lamps. The reaction was allowed to run for $15 \mathrm{~min}$ and then stopped by switching off the light. The tubes were immediately covered with a black cloth. The absorbance was recorded at $560 \mathrm{~nm}$. A non-irradiated reaction mixture which did not develop a color, considered as the control. In the presence of SOD, the reaction was inhibited and the extent of inhibition was used to quantify the enzyme. The absorbance of enzyme extract volume corresponding to $50 \%$ inhibition 
of this reaction was estimated and considered as one enzyme unit. The specific enzyme activity was measured as unit per $\mathrm{mg}^{-1}$ protein.

\section{Malondialdehyde}

Malondialdehyde (MDA) content ( $\mathrm{mmol} \mathrm{g} \mathrm{g}^{-1} \mathrm{FW}$ ) of the leaves was measured according to the method of Janero [19]. A leaf sample $(0.5 \mathrm{~g})$ was homogenized in $5 \mathrm{ml}$ of $5 \%$ trichloro-acetic acid. Then the homogenate was centrifuged at $1800 \mathrm{~g}$ for $10 \mathrm{~min}$ at $25^{\circ} \mathrm{C}$. The supernatant was mixed with $2 \mathrm{ml}$ 2-thiobarbituric acid (TBA), and then the tubes were heated in a Bain Marie for $10 \mathrm{~min}$ at $98{ }^{\circ} \mathrm{C}$. Thereafter, the sample was cooled at room temperature and it was again centrifuged at $1800 \mathrm{~g}$ for $10 \mathrm{~min}$. The absorbance of supernatant was read at $532 \mathrm{~nm}$. A calibration curve was used to estimate malondialdehyde content as $\mathrm{mmol} \mathrm{g}^{-1} \mathrm{FW}$.

\section{Electrolyte leakage}

Leaf membrane damage was determined by recording electrolyte leakage (EL) as described by Valentovic et al. [47] with a few modifications. Plant material $(0.5 \mathrm{~g})$ was washed by deionized water and placed in tubes containing $20 \mathrm{ml}$ of deionized water, and then incubated for $24 \mathrm{~h}$ at $25^{\circ} \mathrm{C}$. Subsequently, the electrical conductivity of the solution (L1) was measured Leaf samples were then autoclaved at $120^{\circ} \mathrm{C}$ for $20 \mathrm{~min}$ and the final conductivity (L2) was measured after equilibration at $25^{\circ} \mathrm{C}$. The EL was calculated as: EL $(\%)=(\mathrm{L} 1 / \mathrm{L} 2) \times 100$.

\section{Statistical analysis}

The data were analyzed by MSTAT-C software after normality test. The means were compared by Duncan multiple range test at $p \leq 0.05$, and the figures were drawn by Excel.

\section{RESULTS}

\section{Photosynthetic pigments}

Chlorophyll $\mathrm{a}, \mathrm{b}$, the ratio of $\mathrm{a} / \mathrm{b}$ and carotenoids were significantly affected by drought stress and growth regulators. Chlorophylls a and b contents were decreased, but the ratio of $\mathrm{a} / \mathrm{b}$ and carotenoid content were increased by decreasing water availability (Table 1, Fig. 1). Foliar applications of polyamines, particularly spermidine, improved the chlorophylls $\mathrm{a}$ and $\mathrm{b}$ content, while the ratio of $\mathrm{a} / \mathrm{b}$ was diminished by 
Table 1

The effects of drought stress and polyamines on photosynthetic pigments of Indian mustard

\begin{tabular}{|c|c|c|c|}
\hline Treatment & $\begin{array}{c}\text { Chl a } \\
\left(\mathrm{mg} \mathrm{g}^{-1} \mathrm{FW}\right)\end{array}$ & $\begin{array}{c}\text { Chl b } \\
\left(\mathrm{mg} \mathrm{g}^{-1} \mathrm{FW}\right)\end{array}$ & $\mathrm{Chl} \mathrm{a} / \mathrm{b}$ \\
\hline$(\% \mathrm{FC})$ & & & \\
\hline 100 & $2.02 \mathrm{a}$ & $1.14 \mathrm{a}$ & $1.78 \mathrm{c}$ \\
\hline 75 & $1.81 \mathrm{~b}$ & $0.92 \mathrm{~b}$ & $1.95 \mathrm{~b}$ \\
\hline 50 & $1.64 \mathrm{c}$ & $0.83 \mathrm{c}$ & $1.98 \mathrm{~b}$ \\
\hline 25 & $1.53 \mathrm{~d}$ & $0.70 \mathrm{~d}$ & $2.18 \mathrm{a}$ \\
\hline Polyamines & & & \\
\hline Water & $1.66 \mathrm{~b}$ & $0.817 \mathrm{~b}$ & $2.07 \mathrm{a}$ \\
\hline Spermidine & $1.81 \mathrm{a}$ & $0.959 \mathrm{a}$ & $1.91 \mathrm{~b}$ \\
\hline Putrescine & $1.78 \mathrm{a}$ & $0.930 \mathrm{a}$ & $1.93 \mathrm{~b}$ \\
\hline
\end{tabular}

Different letters in each column indicate significant difference at $\mathrm{p} \leq 0.05$.

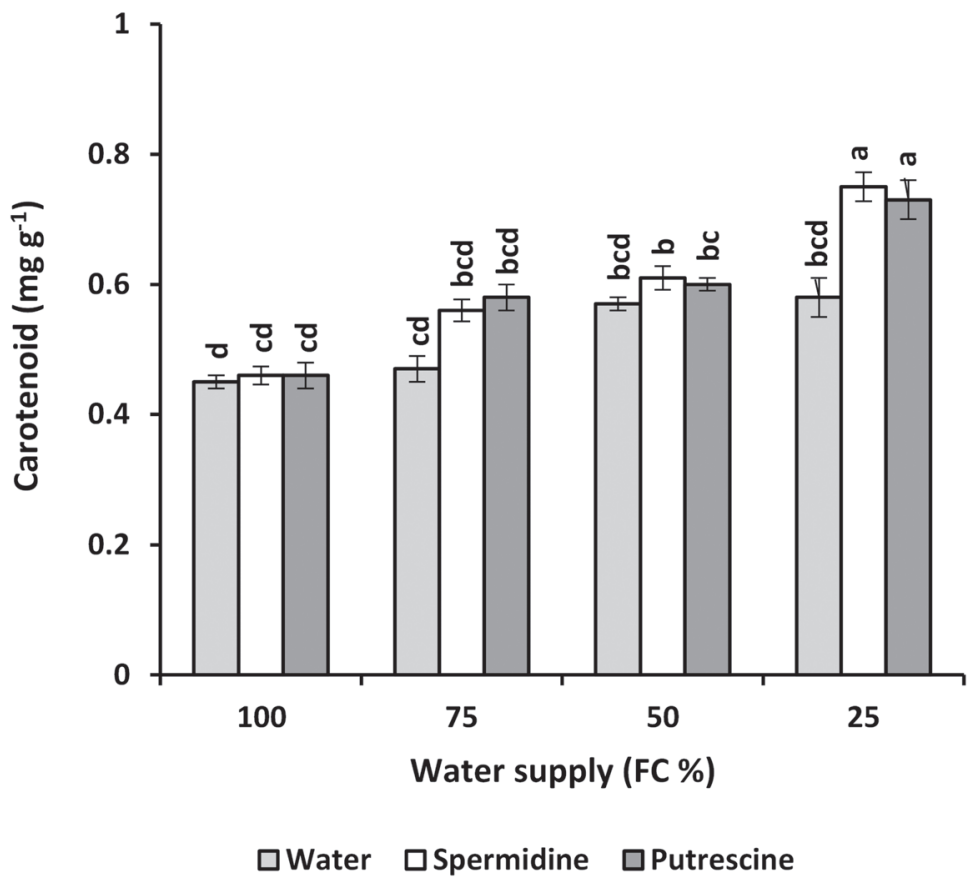

Fig. 1. Changes in carotenoids of mustard leaves affected by spermidine and putrescine under different levels of water supply 
these growth regulators. Foliar sprays of spermidine and putrescin increased carotenoids content of the Indian mustard under limited irrigation conditions (Fig. 1).

\section{Leaf water content}

The interaction between water supply and growth regulator was significant regardity leaf water content. The LWC was decreased by enhancing drought stress. Foliar sprays of spermidine and putrescin increased the relative water content of the Indian mustard under limited irrigation conditions. This improvement was more evident under moderate and severe water limitations, and spermidine proved generally to be the superior treatment (Table 2).

\section{Proline and glycine betaine}

The interaction between drought stress and polyamines was also significant for the proline and GB contents of mustard leaves. Proline and GB contents of leaves were elevated by declining water supply. Foliar sprays of polyamines had no significant effect on proline and GB contents under normal watering, while proline content was decreased and GB content was enhanced by these growth regulators under stressful conditions (Table 2).

Table 2

The effects of drought stress and polyamines on relative water content (RWC), proline, glycine-betaine, soluble sugars and proteins of Indian mustard

\begin{tabular}{|c|l|c|c|c|c|c|}
\hline $\begin{array}{c}\text { Irrigation } \\
(\% \mathrm{FC})\end{array}$ & $\begin{array}{c}\text { Hormonal } \\
\text { treatment }\end{array}$ & $\begin{array}{c}\text { RWC } \\
(\%)\end{array}$ & $\begin{array}{c}\text { Proline } \\
\left(\mathrm{mg} \mathrm{g}^{-1} \mathrm{FW}\right)\end{array}$ & $\begin{array}{c}\text { Glycine betaine } \\
\left(\mathrm{mg} \mathrm{g}^{-1} \mathrm{FW}\right)\end{array}$ & $\begin{array}{c}\text { Soluble sugars } \\
\left(\mathrm{mg} \mathrm{g}^{-1} \mathrm{DW}\right)\end{array}$ & $\begin{array}{c}\text { Soluble proteins } \\
\left(\mathrm{mg} \mathrm{g}^{-1} \mathrm{FW}\right)\end{array}$ \\
\hline \multirow{3}{*}{100} & Water & $90.8 \mathrm{a}$ & $10.72 \mathrm{i}$ & $1.917 \mathrm{~h}$ & $7.56 \mathrm{~g}$ & $3.54 \mathrm{~g}$ \\
\cline { 2 - 8 } & Spermidine & $89.6 \mathrm{ab}$ & $10.67 \mathrm{i}$ & $1.833 \mathrm{~h}$ & $7.79 \mathrm{~g}$ & $3.31 \mathrm{~g}$ \\
\cline { 2 - 8 } & Putrescine & $88.2 \mathrm{~b}$ & $11 \mathrm{i}$ & $2.1 \mathrm{~h}$ & $7.45 \mathrm{~g}$ & $3.40 \mathrm{~g}$ \\
\hline \multirow{3}{*}{75} & Water & $83.5 \mathrm{~d}$ & $38.46 \mathrm{e}$ & $3.58 \mathrm{~g}$ & $11.45 \mathrm{f}$ & $7.21 \mathrm{f}$ \\
\cline { 2 - 8 } & Spermidine & $85.3 \mathrm{c}$ & $21 \mathrm{~h}$ & $3.8 \mathrm{fg}$ & $12.1 \mathrm{f}$ & $8.21 \mathrm{cde}$ \\
\cline { 2 - 8 } & Putrescine & $84.1 \mathrm{~cd}$ & $23.41 \mathrm{~g}$ & $3.9 \mathrm{fg}$ & $13.8 \mathrm{e}$ & $8.84 \mathrm{cde}$ \\
\hline \multirow{3}{*}{50} & Water & $69.4 \mathrm{~g}$ & $49.85 \mathrm{~d}$ & $5.43 \mathrm{e}$ & $19.97 \mathrm{~d}$ & $7.51 \mathrm{ef}$ \\
\cline { 2 - 8 } & Spermidine & $77.2 \mathrm{e}$ & $36.24 \mathrm{f}$ & $6.66 \mathrm{c}$ & $20.45 \mathrm{~d}$ & $10.27 \mathrm{~b}$ \\
\cline { 2 - 8 } & Putrescine & $73.3 \mathrm{f}$ & $38.13 \mathrm{e}$ & $6.2 \mathrm{~d}$ & $22.5 \mathrm{c}$ & $8.03 \mathrm{def}$ \\
\hline \multirow{3}{*}{25} & Water & $57.5 \mathrm{j}$ & $60.33 \mathrm{a}$ & $6.56 \mathrm{c}$ & $32.24 \mathrm{~b}$ & $9.00 \mathrm{c}$ \\
\cline { 2 - 8 } & Spermidine & $66.3 \mathrm{~h}$ & $53.25 \mathrm{c}$ & $7.33 \mathrm{~b}$ & $35.24 \mathrm{a}$ & $11.98 \mathrm{a}$ \\
\cline { 2 - 8 } & Putrescine & $64.4 \mathrm{i}$ & $56.37 \mathrm{~b}$ & $7.7 \mathrm{a}$ & $34.35 \mathrm{a}$ & $10.54 \mathrm{~b}$ \\
\hline
\end{tabular}

Different letters in each column indicate significant difference at $\mathrm{p} \leq 0.05$. 


\section{Soluble sugars and protein}

The interaction between drought stress and polyamines was also significant for the proteins and soluble sugars contents of mustard leaves. Foliar sprays of polyamines had no significant effect on proteins and soluble sugars under normal watering, while their level was enhanced by polyamines under stressful conditions (Table 2).

\section{Antioxidant enzymes activities}

The interaction between water supply and hormonal treatment was also significant for the antioxidant enzyme activities of mustard leaves. POX, CAT, SOD and APX activities enhanced with increasing drought stress. Treatments of plants with SP and PUT under normal conditions did not show any significant effect on POX, CAT, SOD and APX activities. However, these treatments improved the antioxidant enzyme activities of plants by $7.5-124 \%$, depending on enzyme and polyamine types and also on stress level (Table 3).

\section{Lipid peroxidation}

The interaction between water supply and polyamines was also significant for the MDA and EL of mustard leaves. MDA and EL content enhanced with increasing drought stress. Polyamine treated plants showed lower EL and MDA content under stressful conditions.

Table 3

Changes in antioxidant enzymes activities, lipid peroxidation (MDA) and electrolyte leakage (EL) of mustard leaves affected by spermidine and putrescine under different levels of water supply

\begin{tabular}{|c|l|c|c|c|c|c|c|}
\hline $\begin{array}{c}\text { Irrigation } \\
(\% \mathrm{FC})\end{array}$ & $\begin{array}{c}\text { Hormonal } \\
\text { treatment }\end{array}$ & $\begin{array}{c}\mathrm{CAT} \\
\left(\mathrm{U} \mathrm{g} \mathrm{g}^{-1} \mathrm{FW}\right)\end{array}$ & $\begin{array}{c}\mathrm{APX} \\
\left(\mathrm{U} \mathrm{g}^{-1} \mathrm{FW}\right)\end{array}$ & $\begin{array}{c}\mathrm{SOD} \\
\left(\mathrm{U} \mathrm{g} \mathrm{FW}^{-1}\right.\end{array}$ & $\begin{array}{c}\text { POX } \\
\left(\mathrm{U} \mathrm{g}^{-1} \mathrm{FW}\right)\end{array}$ & $\begin{array}{c}\text { MDA } \\
\left(\mathrm{mmol} \mathrm{g}^{-1} \mathrm{FW}\right)\end{array}$ & $\begin{array}{c}\text { EL } \\
(\%)\end{array}$ \\
\hline \multirow{3}{*}{100} & Water & $0.09 \mathrm{~h}$ & $0.53 \mathrm{e}$ & $0.70 \mathrm{e}$ & $0.30 \mathrm{i}$ & $0.82 \mathrm{~h}$ & $17.70 \mathrm{j}$ \\
\cline { 2 - 8 } & Spermidine & $0.09 \mathrm{~h}$ & $0.50 \mathrm{e}$ & $0.60 \mathrm{e}$ & $0.28 \mathrm{i}$ & $0.90 \mathrm{~h}$ & $16.73 \mathrm{k}$ \\
\cline { 2 - 8 } & Putrescine & $0.13 \mathrm{~h}$ & $0.55 \mathrm{e}$ & $0.64 \mathrm{e}$ & $0.30 \mathrm{i}$ & $0.81 \mathrm{~h}$ & $17.43 \mathrm{jk}$ \\
\hline \multirow{3}{*}{75} & Water & $0.50 \mathrm{~g}$ & $0.76 \mathrm{de}$ & $0.85 \mathrm{e}$ & $1.72 \mathrm{~h}$ & $2.50 \mathrm{e}$ & $26.70 \mathrm{~g}$ \\
\cline { 2 - 8 } & Spermidine & $1.12 \mathrm{e}$ & $1.06 \mathrm{de}$ & $0.98 \mathrm{e}$ & $2.00 \mathrm{~g}$ & $1.30 \mathrm{~g}$ & $20.70 \mathrm{i}$ \\
\cline { 2 - 8 } & Putrescine & $0.78 \mathrm{f}$ & $1.30 \mathrm{~d}$ & $0.96 \mathrm{e}$ & $1.91 \mathrm{~g}$ & $2.10 \mathrm{f}$ & $22.00 \mathrm{~h}$ \\
\hline \multirow{3}{*}{50} & Water & $1.83 \mathrm{~d}$ & $3.60 \mathrm{c}$ & $1.70 \mathrm{~d}$ & $2.83 \mathrm{f}$ & $4.60 \mathrm{c}$ & $35.00 \mathrm{~d}$ \\
\cline { 2 - 8 } & Spermidine & $2.63 \mathrm{c}$ & $4.36 \mathrm{~b}$ & $2.50 \mathrm{c}$ & $3.20 \mathrm{e}$ & $4.06 \mathrm{~d}$ & $30.17 \mathrm{e}$ \\
\cline { 2 - 8 } & Putrescine & $2.06 \mathrm{~d}$ & $5.33 \mathrm{a}$ & $2.50 \mathrm{c}$ & $3.52 \mathrm{~d}$ & $4.26 \mathrm{~d}$ & $28.83 \mathrm{f}$ \\
\hline \multirow{3}{*}{25} & Water & $3.06 \mathrm{~b}$ & $4.40 \mathrm{~b}$ & $2.70 \mathrm{bc}$ & $4.00 \mathrm{c}$ & $6.66 \mathrm{a}$ & $41.00 \mathrm{a}$ \\
\cline { 2 - 8 } & Spermidine & $3.70 \mathrm{a}$ & $5.56 \mathrm{a}$ & $3.00 \mathrm{ab}$ & $4.71 \mathrm{a}$ & $5.90 \mathrm{~b}$ & $36.00 \mathrm{c}$ \\
\cline { 2 - 8 } & Putrescine & $3.30 \mathrm{~b}$ & $5.46 \mathrm{a}$ & $3.13 \mathrm{ab}$ & $4.30 \mathrm{~b}$ & $6.06 \mathrm{~b}$ & $38.0 \mathrm{~b}$ \\
\hline
\end{tabular}

Different letters in each column indicate significant difference at $\mathrm{p} \leq 0.05$. 


\section{DISCUSSION}

Water limitation is an important factor restricting plant production in many areas of the world. The plant response to water deficit is either adoptive or detrimental, depending on severity and duration of stress, plant developmental stage and species [11]. Plants under stress alter their metabolic and physiological function to mitigate deleterious effects and prolong survival [3].

Decreasing chlorophyll a and $\mathrm{b}$ contents under water stress may be associated with increasing the activity of chlorophyllase and ethylene production. Improving chlorophyll a, b and caroteonid levels by foliar sprays of polyamines in Indian mustard (see Table 1) was possibly achieved by prevention of Chl loss and preservation of thylakoid membrane structure $[1,5,12]$. It seems that the strongly cationic polyamines may exert their effect by preserving thylakoid morphology and Chl levels through an interaction with the negatively charged loci in the membranes [28].

The enhancement of the leaf water content of the Indian mustard due observed following drought stress (see Table 2), can be attributed to cell wall elasticity [23]. The considerable increment of leaf water content by polyamine application under different levels of watering (Table 2) is most likely resulted in the higher osmotic regulation of plant tissues with lower elasticity caused by these growth regulators [38]. The maintenance of adequate leaf water status is important for proper physiological and biochemical functioning. Maintaining cell membrane stability is also crucial for proper cellular functions, and electrolyte leakage has been widely used to estimate cell membrane stability $[6,36]$.

Leaf proline content was slightly increased in Indian mustard under different irrigation treatments (Table 2). This can help plants maintain water absorption and cell turgor pressure under drought stress [50]. A number of studies showed that proline was positively correlated with osmotic adjustment during drought stress in other plant species $[20,35,49]$. Reduction of proline content by exogenous application of putrescine and spermidine under stressful conditions observed in our study could be caused by the induction of their gene expression $[46,51]$. This could be favorable for chlorophyll synthesis, since chlorophyll and proline are both synthesized from the glutamate. Polyamines can protect plants from stress injuries through their roles in osmotic adjustment, removing reactive oxygen species and maintaining membrane stability [9].

The glycine betaine (GB) content of Indian mustard was improved by foliar spray of polyamines, which may be an adaptive feature for maintaining the water balance under water stress. GB is synthesized in response to salinity or drought stress in some plant species, that regulates osmotic potential ( $\Psi s$ ) and facilitate cellular turgor maintenance [29]. Recently, Chen and Murata [10] have proposed that GB could be also involved in inhibiting ROS accumulation, protecting membrane and photosynthetic machinery, and activating some stress related genes.

Rising soluble sugar levels under stressful conditions see can be related with increasing invertase activity in the mustard. Soluble sugars were shown to act as osmo-regulators and also to stabilize membrane structure, contributing to drought 
tolerance of plants [3]. Increasing soluble protein content observed following water limitation may be associated with the expression of dehydrin-like proteins under this condition [13].

Among the enzymatic antioxidants, superoxide dismutase (SOD) scavenges $\mathrm{O}_{2}{ }^{-}$ free radicals converting them into $\mathrm{H}_{2} \mathrm{O}_{2}$. Then, catalase (CAT) and peroxidase (POD) scavenge $\mathrm{H}_{2} \mathrm{O}_{2}$ into $\mathrm{H}_{2} \mathrm{O}$ and $\mathrm{O}_{2}$ [48]. Although the activities of antioxidant enzymes (SOD, APX, CAT and POX) in Indian mustard were elevated by drought stress, an additional of increase these activities was achieved by foliar application of SPD and PUT. MDA and EL leaves were also enhanced under water stress, more likely due to the peroxidation of lipids and membrane damage. This is a consequence of enhancing reactive oxygen species (ROS) in plants subjected to water deficit. Reduction of MDA and EL contents by SPD and PUT treatments is a direct result of improving antioxidant enzymes activities by these growth regulators.

\section{CONCLUSION}

Water limitation decreased chlorophyll a and b contents but increased the ratio of $\mathrm{Chl}$ $a / b$ and carotenoids in Indian mustard. However, exogenous polyamines enhanced chlorophyll $\mathrm{a}$ and $\mathrm{b}$ and carotenoid contents, while reduced the ratio of $\mathrm{Chl} \mathrm{a} / \mathrm{b}$. Polyamines also improved relative water content, glycine betaine, proteins and soluble sugars, but deduced proline content under drought stress. The activity of antioxidant enzymes (POX, CAT, SOD and APX) was elevated by water deficit and polyamines, leading to lower electrolyte leakage and lipid peroxidation (less MDA) under drought stress. Therefore, foliar sprays of putrescine and spermidine can mitigate some of the harmful effects of water limitation in Indian mustard.

\section{REFERENCES}

1. Anderson, J. W., Rowan, K. S. (1966) The effect of 6-furfurylaminopurine on senescence in tobaccoleaf tissue after harvest. Biochem. J. 98, 401-404.

2. Arnon, D. I. (1949) Copper enzymes in isolated chloroplasts polyphenol oxidase in Beta vulgaris. Plant Physiol. 24, 1-14.

3. Bartels, D., Sunkar, R. (2005) Drought and salt tolerance in plants. Crit. Rev. Sci. 24, 23-58.

4. Bates, L. S., Waldren, R. P., Teare, I. D. (1973) Rapid determination of free proline for water-stress studies. Plant. Soil. 39, 205-207.

5. Biswal, U. C., Mohanty, P. (1976) Ageing induced changes in photosynthetic electron transport of detached barley leaves. Plant Cell Physiol. 17, 323-331.

6. Blum, A., Ebercon, A. (1981) Cell membrane stability as a measure of drought and heat tolerance in wheat. Crop Sci. 21, 43-47.

7. Boyer, J. S. (1992) Plant productivity and environment. Science 218, 443-448.

8. Bradford, M. M. (1976) A rapid sensitive method for the quantification of microgram quantities of protein utilising the principle of protein-dye binding. Anal. Biochem. 72, 248-254.

9. Caldarera, C. M., Rossoni, C., Casti, A. (1976) Involvement of polyamines in ribonucleic acid synthesis as a possible biological function. Ital. J. Biochem. 25, 33-55. 
10. Chen, T. H. H., Murata, N. (2008) Glycine betaine: an effective protectant against abiotic stress in plants. Trends in Plant Sci. 13, 499-505.

11. Demirevska, K., Zasheva, D., Dimitrov, R., Simova-Stoilova, L., Stamenova, M., Feller, U. (2009) Drought stress effects on Rubisco in wheat: Changes in the Rubisco large subunit. Acta Physiol. Plant. 31, 1129-1138.

12. Dennis, D. T., Stubbs, N., Coulate, T. P. (1967) The inhibition of brussels sprout leaf senescence by kinins. Can. J. Bot. 45, 1019-1024.

13. Dunbar, B., Elthon, E., Osterman, C. (1997) Identification of plant mitochondrial proteins: a procedure linking two-dimensional electrophoresis to protein sequencing from PVDF membranes using a fastblot cycle. Plant Mol. Biol. Report 15, 46-61.

14. Foyer, C. H., Noctor, G. (2005) Redox homeostasis and antioxidant signaling: a metabolic interface between stress perception and physiological responses. Plant Cell. 17, 1866-1875.

15. Giannopolitis, C. N., Ries, S. K. (1977) Superoxide dismutases. I. Occurrence in higher plants. Plant Physiol. 59, 309-314

16. Gueta-Dahan, Y., Yaniv, Z., Zilinskas, B. A., Ben-Hayyim, G. (1997) Salt and oxidative stress: similar and specific responses and their relation to salt tolerance in citrus. Planta 203, 460-469.

17. Grieve, C. M., Grattan, S. R. (1983) Rapid assay for the determination of water soluble quaternary ammonium compounds. Plant Soil. 70, 303-307.

18. Hakeem, K. R., Chandna, R., Ahmad, P., Ozturk, M., Iqbal, M. (2012) Relevance of proteomic investigations in plant stress physiology. OMICS J. Integr. Biol. 16, 621-635.

19. Janero, D. R. (1990) Malondialdehyde and thiobarbituric acid-reactivity as diagnostic indices of lipid peroxidation and peroxidative tissue injury. Free Radic. Biol. Med. 9, 515-540.

20. Keyvan, S. (2010) The effects of drought stress on yield, relative water content, proline, soluble carbohydrates and chlorophyll of bread wheat cultivars. J. Animal Plant Sci. 8, 1051-1060.

21. Kochert, G. (1978) Carbohydrate determination by the phenol sulfuric acid method. In: Hellebust, J. A., Craigie, J. S. (eds) Handbook of Physiological Methods - Physiological and Biochemical Methods. Cambridge University Press, London, pp. 96-97.

22. Kumar, A., Altabella, T., Taylor, M. A., Tiburcio, A. F. (1997) Recent advances in polyamine research. Trends Plant Sci. 2, 124-130.

23. Liu, Y., Fiskum, G., Schubert, D. (2002) Generation of reactive oxygen species by mitochondrial electrontransport chain. J. Neurochem. 80, 780-787.

24. Maliwal, G. L., Thakkar, K. R., Sonani, V. V., Patel, P. H., Trivedi, S. N. (1998) Response of mustard (Brassica juncea L.) to irrigation and fertilization. Ann. Agric. Res. 19, 353-359.

25. Masoumi, A., Kafi, M., Khazaei, H. R., Davari, K. (2010) Effect of drought stress on water status, electrolyte leakage and enzymatic antioxidants of Kochia (Kochia Scoparia) under saline condition. Pak. J. Bot. 42, 3517-3524.

26. Mittler, R. (2002) Oxidative stress, antioxidants and stress tolerance. Trends Plant Sci. 7, 405-410.

27. Mittler, R., Vanderauwera, S., Gollery, M., Van Breusegem, F. (2004) Reactive oxygen gene network of plants. Trends Plant Sci. 9, 490-498.

28. Mullineaux, P. M., Baker, N. R. (2010) Oxidative stress: antagonistic signaling for acclimation or cell death? Plant Physiol. 154, 521-525.

29. Munns, R. (2002) Comparative physiology of salt and water stress. Plant Cell Environ. 25, 239-250.

30. Nakano, Y., Asada, K. (1981) Hydrogen peroxide is scavenged by ascorbate-specific peroxidase in spinach chloroplasts. Plant Cell Physiol. 22, 867-880.

31. Noctor, G., Foyer, C. H. (1998) Ascorbate and glutathione: keeping active oxygen under control. Annu. Rev. Plant Biol. 49, 249-279.

32. Pastori, G. M., Foyer, C. H. (2002) Common components, networks, and pathways of cross-tolerance to stress. The central role of "redox" and abscisic acid-mediated controls. Plant Physiol. 129, 460-468.

33. Patel, J. R. (1999) Effect of irrigation and nitrogen on mustard. J. Maharashtra Agric. Univ. 23, $259-261$. 
34. Prochaska, L. J., Gross, E. L. (1977) Evidence for the location of divalent cation binding sites on the chloroplast membrane. J. Membr. Biol. 36, 13-32.

35. Quan, R., Hu, S., Zhang, Z., Zhang, H., Huang, R. (2010) Over expression of an ERF transcription factor TSRF1 improves rice drought tolerance. Plant Biotechnol. J. 8, 476-488.

36. Rachmilevitch, S., DaCosta, M., Huang, B. (2006) Physiological and biochemical indicators for stress tolerance. In: Huang, B. (ed.). Plant-environment interactions. CRC Press, Boca Raton, Florida, pp. 321-356.

37. Resketo, P., Szabo, L. (1992) The effect of drought on development and yield components of soybean. Int. J. Trop. Agric. 8, 347-354.

38. Ritchie, S. W., Nguyan, H. T., Holaday, A. S. (1990) Leaf water content and gas exchange parameters of two wheat genotypes differing in drought resistance. Crop Sci. 30, 105-111.

39. Riznsky, L. H., Liang, H., Hittler, R. (2002) The combined effect of drought stress and heat shock on gene expression in tobacco plant. Plant Physiol. 130, 1143-1151.

40. Roychoudhury, A., Basu, S., Sengupta, D. N. (2011) Amelioration of salinity stress by exogenously applied spermidine or spermine in three varieties of indica rice differing in their level of salt tolerance. J. Plant Physiol. 168, 317-328.

41. Sharma, P., Dubey, R. S. (2005) Drought induces oxidative stress and enhances the activities of antioxidant enzymes in growing rice seedlings. Plant Growth Regul. 46, 209-221.

42. Sharma, P., Jha, A. B., Dubey, R. S., Pessarakli, M. (2012) Reactive oxygen species, oxidative damage, and antioxidative defense mechanism in plants under stressful conditions. J. Bot. 7, 1-26.

43. Singh, B. K., Sharma, S. R., Singh, B. (2010) Antioxidant enzymes in cabbage: variability and inheritance of superoxide dismutase, peroxidase and catalase. Sci. Hortic. 124, 9-13.

44. Sonntag, N. O. V. (1995) Industrial utilization of long-chain fatty acids and their derivatives In: Kimber, D. S., McGregor, D. I. (eds), Brassica Oilseeds. CAB International, Oxford shire, pp. 339-352.

45. Tabor, C. W., Tabor, H. (1999) It all started on a streetcar in Boston. Annu. Rev. Plant Biol. 68, 1-32.

46. Tanou, G., Ziogas, V., Belghazi, M., Christou, A., Filippou, P., Job, D. (2014) Polyamines reprogram oxidative and nitrosative status and the proteome of citrus plants exposed to salinity stress. Plant Cell Environ. 37, 864-885.

47. Valentovic, P., Luxova, M., Kolarovic, L., Gasparikova, O. (2006) Effect of osmotic stress on compatible solutes content, membrane stability and water relations in two maize cultivars. Plant Soil Environ. 52, 186-191.

48. Wang, J., Liu, J. H. (2009) Change in free polyamine contents and expression profiles of two polyamine biosynthetic genes in citrus embryo genic callus under abiotic stresses. Biotechnol. Eq. 29, 1289-1293.

49. Xiong, J., Zhang, L., Fu, G., Yang, Y., Zhu, C., Tao, L. (2012) Drought-induced proline accumulation is uninvolved with increased nitric oxide, which alleviates drought stress by decreasing transpiration in rice. J. Plant Res. 125, 155-164.

50. Yokota, A., Takahara, K., Akashi, K. (2006) Water stress. In: Madhava-Rao, K. V., Raghavendra, A. S., Janardhan-Reddy, K. (eds), Physiology and Molecular Biology of Stress Tolerance in Plants. Springer, Berlin. pp. 15-40.

51. Zhang, Y., Zhang, H., Zou, Z. R., Liu, Y., Hu, X. H. (2015) Deciphering the protective role of spermidine against saline-alkaline stress at physiological and proteomic levels in tomato. Phytochem. $110,13-21$ 